\title{
Article
}

\section{Who Are You Calling a Hackney Twat? \\ Gender and Stigma in Media Representation}

\author{
Charlie Athill \\ London College of Fashion, University of the Arts London
}

\begin{abstract}
This article explores attitudes in the United Kingdom towards male dress, grooming and lifestyle choices, in relation to concepts and accusations of pretentiousness. Taking the recent and broadly defined phenomenon, the 'hipster', as a case study, I analyse discourse in the last decade from a range of media that feature hipsterism. Nearly all media coverage of hipsters has focused on men, reflecting gendered cultural prejudices about styles that require a certain level of both cultivation and maintenance. I investigate how parody conveys cultural distaste, which I contend, mask anxieties about the subversion of norms regarding gender and class. I consider the question of classification with regard to hipsters and the role of stereotyping. By drawing on Dan Fox's (2016) defence of pretentiousness as a catalyst of cultural innovation, I consider taste in relation to authenticity and pretentiousness with regard to what is represented as male hipster adornment. I propose that while attitudes to gender and class have been reformulated, media critique of styles labelled as pretentious reveals entrenched, if repackaged, cultural prejudices and insecurities.
\end{abstract}

Keywords Hipsters, critical media discourse, pretentiousness, authenticity, masculinities, lifestyles, stereotypes, stigma, class, taste

So, what of the hipster? This figure, now evident on a global level through a supposedly recognisable index of stylistic attributes and lifestyle habits, has been the subject of a considerable amount of media scrutiny. Furthermore, much discourse on the subject in both the media and in relevant literature has become, if not exhausted, then recycled. This study offers a dissenting postscript to the mythologised phenomenon of hipsterism in the United Kingdom. This trope for post-millennial anxieties continues to connote, not only particular tastes in lifestyle and appearance, but also an ethos that informs this taste. As a subject, hipsterism, it seems, is no longer addressed by the media as newsworthy, and as with so many other discernible shifts in taste heralded by the media, the absorption of many of its identifiable features into the mainstream have rendered it unremarkable. That said, a good deal has been attributed to hipsters, as any Google search will confirm; however, in a limited field of study dominated by literature from the United States (Bot 2012; Greif, Ross and Tortorici 2010; Kinzey 2012) and continental Northern Europe (Maly and Varis 2016; Michael 2015; Schiermer 2014), a specifically British context is at present underrepresented (Hubbard 2016; Wessendorf 2013). This study focuses on London and is an analysis of British media content from 2010 to 2016, a historical window that corresponds to the period in which the hipster had become au courant in the British media until the inevitable predictions of its demise.

I argue that during this period 'hipster' became a convenient adjectival signifier for consumption habits considered aesthetically and symbolically deficient despite, and 
perhaps because of, the diffusion of their influence. Already in 2010 Ruby Warrington claimed in the Sunday Times that the 'incredibly irritating hipster look has gone global,' (Warrington 2010) when reporting an anti-hipster backlash due to apparently offensive lifestyle cues. Since then the broad consensus in the UK media is that 'the hipster is not a well-liked figure' (Schiermer 2014, 167). Although closer scrutiny of mainstream media reveals a certain, cautious degree of defence, and in social media some spirited challenges to prejudicial attacks, by 2016 most representation of the hipster placed this figure somewhere between a contemporary jester and a neo-liberal folk devil.

My study operates as a reflective critique of public discourse dependent on casual and facile stereotyping and prejudicial assumptions. As theoretical guidance, I take Dan Fox's (2016) radical reappraisal of the cultural value and significance of pretentiousness. Fox issues a call to arms for a deconstruction of a wide range of contemporary doxas across the ideological spectrum. Without pandering to a reactionary agenda, or adopting a fixed ideological view within the simplistic, conventional dichotomy of 'left' and 'right', Fox questions associations and assumptions made about the nexus between class, taste and gender, and in doing so he offers a radical reappraisal of artifice as a positive aspect of social performance. This study is concerned with media representation of male hipsters, for reasons outlined below. Through employing a set of redefinitions of this usually embodied abstraction, the male hipster, alongside a contextualised analysis of authenticity, stereotyping and stigmatisation, I challenge assumptions made in lexical and visual media representation by interrogating both the veracity of specific representations and the premises that underpin them.

\section{Methodology}

This study is positioned as an initial inquiry that follows an 'inter-disciplinary approach to language' that seeks to understand the way discourse operates in 'social processes' (Flowerdew and Richardson 2017, 21), of which the effects of media representation is one. It draws on a range of established qualitative methodological frameworks and approaches, within critical discourse analysis, to explore representation in the media as a 'symbolic environment'. In this, certain 'agendas' played out (Shoemaker 2014, 4) are informed by discourse 'underpinned by ideologies' (Flowerdew and Richardson 2017, 21). Broadly, the term ideology follows the conception of power and influence as proposed by the Gramscian notion of 'hegemony' (Gramsci, Hoare and Nowell-Smith 1971), a form of 'third power' (Lukes, 2005) that acts as an internalised means of persuasion that may 'appear natural ... common sense, and thus ... often invisible' (Durham and Kellner 2006, xiv); as such, ideology can be understood as not merely reflected in socio-cultural attitudes but also as a structuring agent. Media representation of hipsters has reinforced what Flowerdew and Richardson refer as an 'us versus them situation' (Flowerdew and Richardson 2017, 23); however, a salient reminder would be the Gramscian assertion that hegemony itself can be contested by counter-hegemonic forces (Durham and Kellner 2006, xv).

I use a 'multi-modal' social semiotic approach, involving a consideration of not only lexical but also 'visual and aural ... systems of signs' (Flowerdew and Richardson 2017, 21) to consider how these elements structure and perpetuate 'society's ideologies ... and 
legitimise certain kinds of social practices' (Machin and Mayr 2012, 13). As this study interprets the ways in which social actors are classified, it marries semiotic analysis (Barthes 1977) with an analysis of rhetorical devices, which Aristotle refers to as 'modes of persuasion' (Berger 2016, 89). These include allusion, euphemism, irony and metaphor (Berger 2016, 96), and also, of course, hyperbole (Machin and Mayr 2012, 101). Furthermore, van Leeuwen's method of identifying 'collectivisation' through 'genericisation' (van Leeuwen 1996 Machin and Mayr 2012, 50), which relates to 'homogenised' representation in the form of 'stereotypical representations of dress, hairstyle and grooming, and ... often exaggerated features' (Machin and Mayr 2012, 62), assists to identify collectivised stigmatisation through an index of 'attributes ... ideas and values communicated by objects' (ibid.) and reveals sentiments and judgements concerning hipster taste. The research and theme of this study are informed by the interdisciplinary approach employed in cultural studies. This field takes a 'social constructionist' perspective (Jorgensen and Phillips 2002, 4), which facilitates an interpretative approach in which 'the relationship between data and concepts is fundamentally open' (Gunter 2000, 9), and as Chris Barker summarises, 'cultural studies does not speak with one voice' (Barker 2012, 4).

The study draws on a range of mainstream media in digital form, websites, social media and YouTube, within the prescribed period. These contain explicit reference to hipsterism or allusions to it through established 'identity indexicals', signs that connote a particular demographic (Maly and Varis 2016). They are also identifiably British, or are cited by British media as relevant, and focus on London. Regarding moving image, again, the material is British and includes television documentary with explicit reference to hipsterism, and also television and online comedy from various genres. Two television satires, the piloted Shoreditch Twat TV (2002), and Nathan Barley (2005), only available online and both from outside the period in question, are included on the grounds that both have subsequently been cited in the media as representations of hipsterism, despite the term not having entered the public lexicon in the United Kingdom when they were broadcast. Such subsequent associations are significant as they highlight the broad application of 'hipster' to describe a type whose appearance may not correspond to any of the identity indexicals recognised in the period of study but who nevertheless qualifies for reasons of unappealing demeanour or sartorial absurdity. Due to the ephemeral nature of social media, some content has been moved or deleted since my research. One significant source, the blog HackneyHipsterHate can now only be accessed by signing into Tumblr and no longer contains images. Another, the mockumentary, Dalston Superstars (2011), created by Vice UK, features the personal and professional dramas of a group of spectacularly dysfunctional and untalented millennials sharing a Hackney flat. Four episodes and several exposés were run but later removed, with only two of the latter now accessible on Youtube.

\section{Definitions}

The current use of the term 'hipster' emerged at an imprecise point around the millennium in the United States. Originally used to describe members of the post-war African-American counterculture outlined by Anatole Broyard (1948), and subsequently in an analogous 'white' application by Norman Mailer in 1957 (Mailer 1970), the hipster has now come to represent an abiding stock character on the contemporary 
global stage, and one that has become indivisible with a range of cultural shifts in material culture. While the term is proposed, and applied, by the media as an identity marker, it is seldom claimed. This form of labelling operates as the converse, almost antithesis, of Althusser's (1971) notion of interpellation and merely reinforces a disassociation for those to whom the label is applied. Nevertheless, the term is widely understood as something that exists in a recognisable form, and in terms of discourse the concept of hipsterism has moved from the niche to the mainstream. However, it is this very ubiquity, and the broad adoption of so many of its supposedly defining features within the mainstream, that leads to the credibility of the moniker itself being questioned. A generalised, woolly denotation is common to, and perhaps expected from, the media; however, this lack of definitional clarity is shared by the academic literature, which leads to proposed connotations, then classification and ultimately to cultural signification.

In the United Kingdom the term 'hipster', with its present connotations, was adopted later that in the United States; however, by 2013, as journalist, Karen Dacre, points out, it had been 'bandied about' indiscriminately (Dacre 2013), and had become established as a ready moniker for not only a range of lifestyle and sartorial choices but also particular forms of social interaction. These choices were informed by a mind-set and were exemplars of wider socio-economic developments. In terms of establishing a discourse in the British media about the causes and effects of hipsterism, seminal denunciations by Canadian pundit, Douglas Haddow, and also by New York cultural critic and publisher, Mark Greif, are repeatedly cited by the British media as theoretically credible justifications for hipster-bashing, despite the first being a short article in Adbusters, in which Haddow, decrying the vacuity and alienation of hipsters, accuses them, with some hyperbole, as 'representing the end of civilization' (Haddow 2008). Greif extends this train of thought, as editor and contributor to What Was The Hipster (Greif, Ross and Tortorici 2010) and also in media variations of it (Greif 2010a, 2010b). Firstly, they provide a foundational, collective character flaw for hipsters: inauthenticity. This is cited subsequently at all levels in the media. Secondly, despite the specifically North American context of both, they are taken as universally representative examples. Certain similarities between London and New York exist in terms of multicultural composition, socio-economic issues and creative and financial dominance, but it would be an error to read them as merely mirror images of the other.

Changing employment patterns and socio-cultural developments have led to an influx of a 'creative class' (Florida 2014), in Brooklyn and Hackney, and this in turn has produced 'cultural clusters' (Mommaas 2004) of young professionals, many of whom originate from outside these boroughs, and whose presence has accelerated gentrification processes that remain contentious. Not only have rents and property prices risen, creating a housing crisis but transformations in retail and leisure outlets means the very character of these urban areas has been transformed. Hipsters, who provide the recognisable embodiment of this creative class, are therefore characterised as identifiable interlopers who do not really belong, and as such are inauthentic residents. The fact that many belong to the precariat does not provide them working class credentials, but only reinforces allegations of affecting impecuniousness; another form of inauthenticity. Nevertheless, these boroughs are not simply duplicates of one another, and cultural and political histories, ethnic dynamics and local governance are quite 
distinct. Similarities in lifestyle and consumption do not constitute global uniformity and simply superimposing American experiences and contexts onto British ones ignores the transnational nature of hipsterism (Maly and Varis 2015). An example of this is Greif's claim that trucker caps and 'wife beaters', connote 'the violence, instinctiveness and rebelliousness of lower-middle-class suburban or country whites' (Greif, Ross and Tortorici 2010,10), has no meaning in a British context in which class, its socio-cultural implications and its visual signifiers are read differently.

\section{Categorisation}

The various conceptualisations of hipsterism reflect the 'opaque and fluid' nature of it (Maly and Varis 2016, 637). Though often classified as a subculture by media of all types, Bennett points out, subculture has become 'little more than a convenient "catchall" phrase for any aspect of social life in which young people, style and music intersect' (Bennett 1999, 599). However, this has impacted on its reception; the early conception of a subculture as 'heroic' and 'revolutionary' (Hebdige 1979; Hall and Jefferson 1993) has established credentials that resonate with pundits, particularly male critics, who insist that a lack of ideological zeal encapsulates a fundamental lack of anything meaningful in hipsterism.

Regarding subcultural identity, some sense of affiliation is surely a prerequisite, and there is hardly any evidence of this amongst those identified as hipsters. In fact, accusations of hipsterism are usually met with fierce denial. In relation to this, a significant paradox is unexplored by the media: namely, we live in an era in which selfidentification, regarding sex, gender, class or ethnicity, is taken extremely seriously, and there is a widely-held, and increasingly officially-sanctioned belief that claims to identifications and affiliations are an individual's inalienable right. Therefore, for the media to assign an identity, with no regard to the recipient's agency, not only goes against the grain of cultural sensitivity, it also assumes the role of 'moral entrepreneur' (Becker 1964), and one that reifies a stereotype of its own invention.

However, in order to understand hipsterism beyond the aggregated sum of disconnected individuals, alternatives to subculture should be considered. Maffesoli's notion of the 'neo-tribe' (Maffesoli 1996), as proposed through Bennett goes some way to offering a practicable conception of the fluid collective described as hipsterism (Bennett 1999). This neo-tribe, which acts as a 'sociality,' an 'organic structure,' (ibid.) offers, according to Schiermer, a plausible typology as this is really an amalgamation of groups that share, or are perceived to share, a certain approach to style and lifestyle (Schiermer 2014). In relation to these perceptions, certain aspects seen as common to diverse forms of hipsterism evoke what Maffesoli refers to as Stimmung (atmosphere), as this concept provides a means by which interaction between social micro-groups 'is expressed by a succession of ambiences, feelings and emotions' (Maffesoli 1996, 11). Media identification is firmly based on consumption patterns and their embodiment in dress and grooming. Similarly, this can be understood in Shields's reference to lifestyle that draws upon both Weber's 'affective groupings' (1978 in Shields 1992, 13) and Simmel's 'sociations' (1950 in Shields 1992, 14), which 'emerge through the medium of shared symbolic codes of stylized behaviour, adornment, taste and habitus' (Bourdieu 1971 in Shields 1992). 


\section{Authenticity}

As Cobb contends, we are 'surrounded by the rhetoric of authenticity' (Cobb 2014, 2). From the marketing of goods in 'modern consumer culture' (Filitz and Saris 2015, 5) to the assurance of its qualifying properties for those in authority, authenticity is an 'ideal or exemplar' and also a 'marker of status' in late modernity (Vannini and Williams 2009, 4). From a Romantic philosophical perspective, Rousseau binds authenticity to the notion of subjectivity, the individual and uniqueness, and his belief that not only do humans have the capacity to show difference, but indeed should show this, resonates today (Varga 2012, 21). Trilling identifies the transformation of sincerity as a 'moral ideal' for social performance and the public good 'into the ideal of authenticity with the evolution of modernity' (Trilling 1972 cited in Varga 2012, 16). The notion of being true to oneself, informed by 'sincerity for its own sake (Ferreira 1993 cited in Varga 2012 , 16) binds authenticity to honesty and suggests a purity of spirit, the binary opposite of which is an essence contaminated by inauthenticity. Relevant too, is a twopronged conception of authenticity in late modernity in which Taylor identifies both a romantic sensibility, which favours 'an essentialist cultural context turning objects into what is considered traditional' and also, conversely, revolutionary fervour, as the authentic can be located 'from within avant-garde culture' (Taylor 1991, 18). This dichotomy is echoed by Keightley in his analysis of authenticity in rock music, in which he states that 'romantic authenticity emphasises the rural, while Modernist authenticity values the urban' (Keightley 2001, 138), and applied by Michael in her study of taste, consumption and hipster identity (Michael 2015). These distinct approaches symbolise metaphors of nostalgia on one hand and progression on the other. What both have in common is a notion of a corrupting 'other' that disrupts authenticity; in the first instance this is represented by material simulacra and in the second by that which fraudulently claims radical credentials. In both cases, an accusation of inauthenticity transforms the object in question into a meritless parody of the genuine.

\section{Representation and Stereotyping}

Sobel's very obvious point that lifestyles are 'recognisable' (Sobel 1981 in Chaney 1994, 11 ) is fundamental to the representation of hipsters; however, at a time of enormous social and demographic change in what is seen as the heartland of hipsterism, East London, 'new forms of distinction are being continually elaborated'; however, these are met, at best, with grudging respect in terms of culinary innovations and at worst with 'repugnance' in the case of manner and appearance (Chaney 1994, 6). For the most part, derision appears to be the rationale behind a satirical representation. For the media, stereotyping is an established, easy and popular means by which particular demographics can be organised into beneficial commodities: it sells copy. Strategic use of stereotyping also maintains status and what all forms of media require is 'symbolic capital' (Bourdieu 1984, 1993) in order to remain relevant.

Dyer refers to Klapp's distinction between the definition given to 'social groups' as belonging, and stereotypes 'as those who do not belong' (Klapp 1962 in Dyer 2015, 14). Goffman's identification of stigma, triggered by prejudices aroused by perceived flaws in character and appearance and also tribal affiliation, is pertinent. Portrayals of male hipsters, via rhetorical devices and powerfully connotative imagery, offer stereotypical and 'discrediting' (Goffman 1963, 3) representations that suggest that cultural attitudes 
regarding conceptions of masculinity in appearance and manner have not progressed as far as it is claimed, ironically, by a wide range of media.

One reason, perhaps, that the stereotyping of male hipsters is so ubiquitous is because it centres on a mythical other and is largely dependent on either fictional characters or anonymous members of the public, both of which are often recycled and passed between different media formats. Not only do stereotypes 'distort ways in which social groups are characterised' (Pickering 1995, 691), but it is imperative that they do so. There is clearly a logic in the rhetorical need to 'proclaim' as 'effectiveness ... resides in the way they invoke a consensus' (Dyer 2013, 14). This highlights the essential problem with stereotyping, which is not in the reductive and generalised grouping of people but rather in the possible motives for doing so; furthermore, in whose interests is this being done? Berger and Luckmann's analysis of 'the social construction of reality' (Berger and Luckmann 2013, 12) returns us to the reality that media representations are 'grounded in social power' (ibid.), and one that helps naturalise the reproduction of certain views.

While certain features, such as facial hair and skinny jeans, are routinely described as hipster indexical markers, the epithet is also applied to a range of other styles and the arbitrary nature of dress and grooming signifiers are highlighted in media representation. The hipster becomes an abstraction that is superimposed onto whoever conforms to a selected exemplar of urban myth. Sophy Bot describes the hipster 'as elusive as a unicorn yet as common as an ant' (Bot 2012, 151) and social commentator, Chris Mandle, questions whether 'hipsters really exist ... it's smoke and mirrors' (Mandle 2014). Hipsterism is identified in different guises: in a slavish adherence to craft and sustainability, but also, conversely, in tasteless exhibitions of kitsch and artificiality. It is recognised in the neo-Victorian paterfamilias beard and the manicured ruggedness of the lumbersexual. It is identified in a range of normcore and adaptations of historical subcultural styling, expressed by the body-conscious combo of skinny jeans and deep V ' $\mathrm{T}$ ' shirt, in a range of elaborate clubwear, and also, of course, in any form of androgyny. In both mainstream and social media this promiscuous inventory is expressed explicitly through the combination of imagery and the nomenclature 'hipster', and also implicitly in visual and written texts that emphasise associative traits, such as the 'Top Chumps' caricatures, on the defunct website Wepwecan, of which only two can now be accessed on Vice UK (Vice 2018). However, what links these diverse examples is the common factor of perceived pretentiousness. While different, they are all ridiculous because they are overly constructed, and so contrived.

\section{It's All About Men}

The emphasis on male expression is brought into sharp focus in the BBC4 documentary The Hipster Handbook (2016), fronted by seasoned social commentator, Peter York. Presented as an ostensibly objective, retrospective account of hipsterism, it nonetheless explores the rise of the phenomenon through a range of hackneyed identity markers and consumption habits, drawing on a range of pundits from academia, media and fashion. Two aspects of the documentary are salient: the blurring of distinctions between London and New York and the almost total reliance on men as the embodiment of hipsterism. Thirteen minutes into the commentary, York reassures the viewer that hipster women exist before immediately returning to men for the remaining forty-seven minutes. 
The British media has a complicated relationship with men's fashion and the men who follow it. Both tradition and innovation, as two distinct sartorial approaches, are respected; however, men need to qualify convincingly for membership of either camp. As outlined by Varga, this corresponds to a Hegelian sense of sincerity, itself a perpetuation of a classical conception, which is 'not essentially a personal but rather a social virtue' (Varga 2012, 15). When fashion, particularly men's fashion, moves too far from an accredited form or function, it loses its sincerity and virtue. The perceived irony and playfulness of certain styles associated with hipsters can only act to discredit it (see Figure 1. below). In the Spectator, Harry Mount laments 'the knowing irony that's so trying ... they think they look good, clever, amusing. They end up being completely derivative' and he concludes that 'it's bohemianism without the dirt' (Mount 2014).

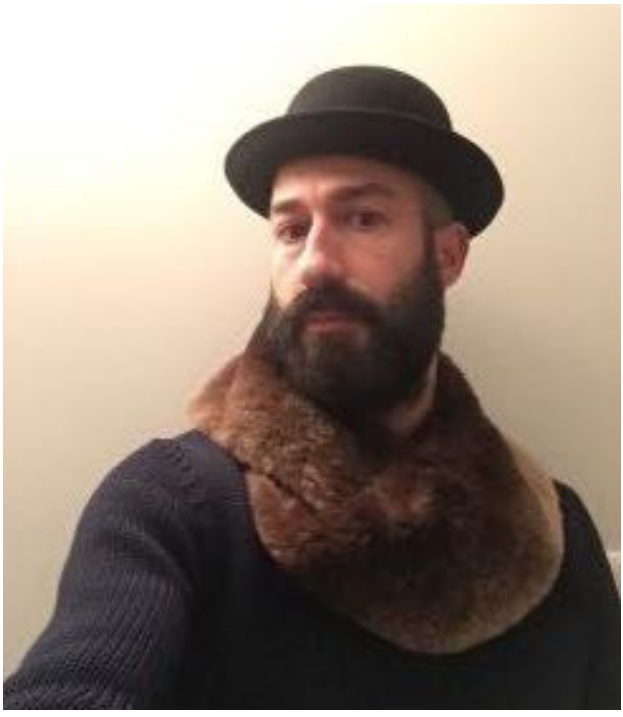

Fig.1. Self Portrait in a Bowler Hat, source: Peral 2015.

In relation to inauthenticity, masculinity itself is represented as dubious when in hipster form. In both social and mainstream media, associations drawn between artifice with unmanliness cast hipsters as inauthentically masculine. Ferrier (2014) cites Boston-based blogger, Luke O'Neil, a selfconfessed hipster, and therefore a rare case. Aside from highlighting the indiscriminate application of the term 'hipster', O'Neil notes astutely that much of the discourse on men comes from men, which brings to mind Demetriou's (2001) notion of 'internal masculinity' through which an 'ascendancy' is maintained by certain men over others. This suggests lingering male discomfort about the enactment of gender by hipsters, who appear 'in a way very feminised, stereotypically speaking ... caring about how you look at all in the first place, even if it's caring to look intentionally gross' (O'Neil 2013). This discomfort suggests a male insecurity, which is manifested according to specific temporal and cultural contexts, and which is fed by the very effort involved in hipsterist presentation; this effort is conflated with artifice, and as such undermines notions of what is deemed normative masculinity.

A great deal has been written about the 'ridiculous clothes, and ... ridiculous facial hair' of male hipsterism (Hackney Hipster Hate, 2010). Moustaches, and the more common beard, were denounced the moment they were noticed. Perceived by many as signifiers of a mind-set, rather than simply fashion, journalist Alex Proud, sums up the opposition: 'What I hate more than Shoreditch itself is the idea of Shoreditch ... I hate the stupid beards and skinny jeans' (Proud 2014). However, these two signifiers of hipsterism have 
had a major impact on how men choose to present themselves. Regarding beards, the close advent of the gay bear and the hipster, often one and the same in East London, is worth noting as both have appropriated a metaphor of orthodox masculinity (Anderson 2012) (see Figure 2 below). In so doing they have subverted preconceptions of the relationship between gender and taste and contributed to a more 'hybridized masculinity' (Beynon 2000, 6), which is increasing evident in popular and material culture.

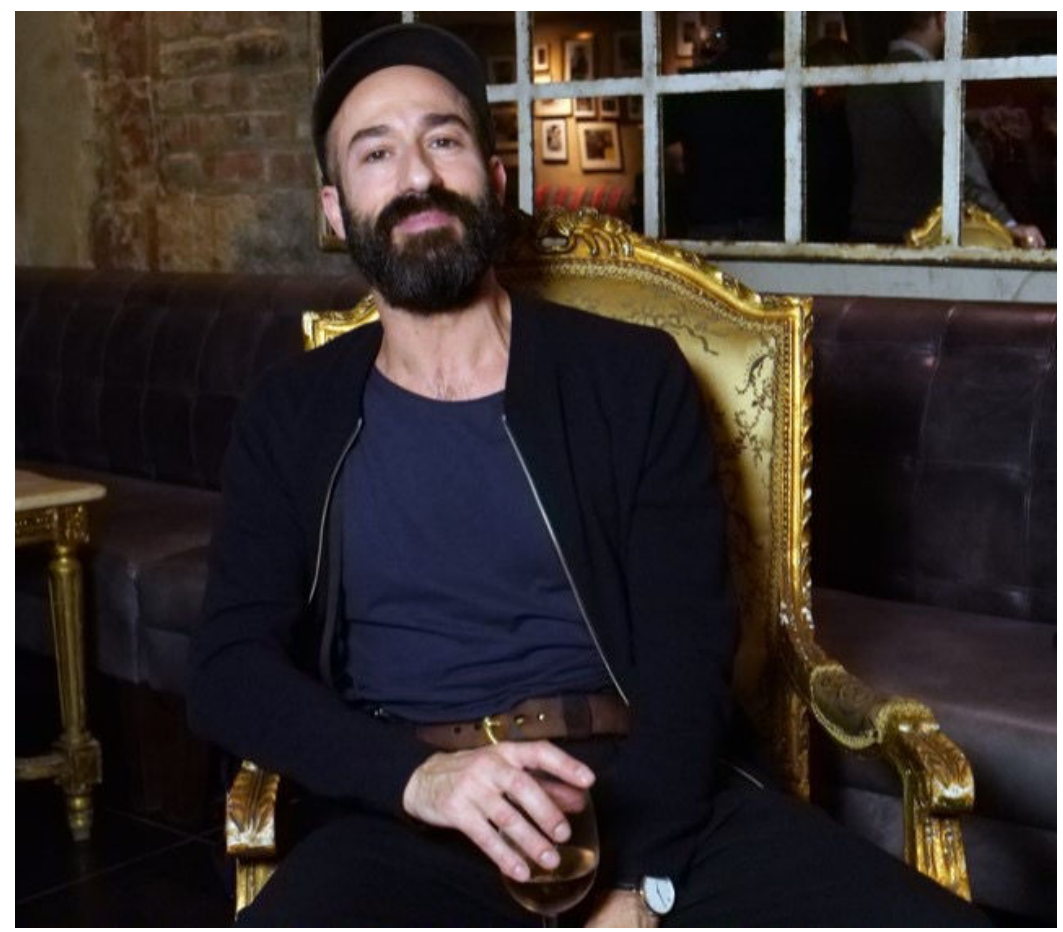

Fig. 2. Taking in the Scene, source: Peral 2016.

\section{Hyperbole and Humour}

Two satires repeatedly mentioned in recent media as early examples of British hipsterism are Shoreditch Twat TV (2002) and Nathan Barley (2005). These take the emerging, and subsequently labelled, 'flat white economy' (McWilliams 2015), which has provided considerable employment and creative opportunities in East London, as the basis on which to lambast a perceived cultural fatuity. These sources are cited as providing an adequate context for hipsterism after 2010, with representations of absurdity, pretentiousness, superficiality and anti-social insularity, but both are heavily stylised and exaggerated in the tradition of British satire that can be traced back to 
eighteenth-century caricature. Characters in neither bear any stylistic resemblance to what subsequently emerged in East London and then elsewhere in the United Kingdom; however, the eponymous Nathan Barley is hailed as the original hipster, a term never applied in the programme itself, on the basis of his self-delusion and general awfulness.

In terms of representation, hipster bricolage is exaggerated to the level of pantomime for full comic effect. In the TV farce Toast of London, centred on the antics of failed actors, styling and characterisation draws heavily on an established British tradition of caricature and social satire and also post-modern irony. Costumes chosen to represent hipsterism in the form of Danny Bear and Clem Fandango are deliberately hyperbolised (Berry and Matthews, 2012-2015). These parodies of the creative class, who run a voiceover studio, resemble the male characters in the earlier, Shoreditch Twat TV (2002) and Nathan Barley (2005), and function as signifiers of absurdity, styled in a selection of bizarrely eclectic, almost dada, costumes. Less extreme but similarly facile is Barney Lumsden in Twenty Twelve (Morton 2011-12) and W1A (Morton 2014), which satirise respectively the London Olympics and the BBC. This character, the 'Go-To Guy' from PR company, 'Perfect Curve: Digital Strategy', communicates through clichéd soundbites, the idiocy of which is reinforced by his white-man afro and nouveau-fogey styling. This is mirrored by Siobhan, his boss, who holds forth in a contemporary flat tone on themes that parody the supposed concerns of East London's 'flat white culture' (McWilliams 2015), while displaying a total ignorance of anything outside the latest fads in fashion or popular culture. Interestingly, unlike Barney, she is styled in contemporary high fashion as opposed to a parody of it, which highlights a gendered differentiation in the visual representation of hipsterism. What all these portrayals have in common, beyond parody, is a conflation of stupidity and superficiality with stylistic artifice.

It is precisely by maintaining a look that requires effort, by trying hard, that hipster men have renegotiated masculinity, and as that labelled 'hipster' comes in a variety of forms, this renegotiation also comes on different levels. Few mainstream journalists would risk professional suicide with outright homophobia, but as Fox posits, 'the insult of 'pretentious' is deployed as an insidious euphemism for ... 'effeminacy' or 'dandyism' (Fox 2016, 130) which acts as the more coded insult. The anonymity of social media, of course, allows for a more explicit reaction and on HackneyHipsterHate, Toastfinger refers to male hipsters as 'a bunch of pretentious cock-ends, mincing about in their offensive dandy-rags' (Hackney Hipster Hate 2010). While this does not explicitly refer to being gay, it suggests a form of 'subordinated masculinity' combined with an inversion 'marginal sexuality' (Connell 2005, Connell and Messerschmidt 2005) that connotes an elitist and emasculated 'other'. This reflects an old prejudice that reads attempts at sophistication as suspect on several levels. Fox contends that 'we smell pretentiousness when we believe something is trying to stay out of reach from us' (Fox 2016, 111) and in contemporary Britain, being perceived as 'try hards' (Hackney Hipster Hate 2010) is interpreted as a form of emasculation produced by effort, of being 'poncey' and the antithesis of a 'regular bloke.' Hipsterism seems to jar with a Nineties Laddism that is still very evident. Those who offer a more political critique decry a superficiality and materialism that signifies inauthenticity from a more radical perspective (Keightley 2001). Those with a more conservative agenda interpret experimentation as foolish and immature and thus indicative of an arrested cultural 
development that is symptomatic of contemporary society. However, as Fox observes, 'claims to ordinariness and salt-of-the-earth virtue ... are themselves pretentious' (Fox 2016, 58).

Representations of hipsterism reveal it as selectively nostalgic in spirit, and although not overtly ideological, it draws on a spectrum of countercultural influences. Its various manifestations can be defined, if rather imprecisely, as postmodern: eclectic, experimental and often retro. Both self-consciously playful and unconventional, it stands outside the perimeters of established taste, drawing on the past, while introducing novel ways of presentation. In this sense, it can be both extremely familiar in spirit, as it combines references to bohemian dress from a number of previous decades, but also innovative as it rearticulates aesthetics through bricolage. As such, it offers an 'oppositional' aesthetic (Wilson 2003, 184) and follows an art-school aesthetic and tradition that it playfully referential.

Most media reaction would suggest that these reinterpretations of past styles are generally not accepted as honest forms of bricolage, in contrast to those supposedly heroic subcultures. Rather, they are dismissed as empty mimetic gestures that reveal, through their shallow consumption of authenticity, an intensification of inauthenticity (Greif 2010, Kinzey 2012). As Alex Miller, editor of Vice UK points out, 'hipster has simply become a word which means the opposite of authentic' (Ferrier 2014). This reading conceptualises appropriation as blind imitation. Consumption itself is regularly conflated with a lack of ideological commitment and is therefore understood as a conscious abjuring of radical engagement with class struggle, which compounds accusations of 'play acting' (York 2016), and of a cynical parodying of 'heroic' precursors, which, naturally, is cited as evidence of inauthenticity. However, Schiermer contends that 'new phenomenologies and sensibilities' have been made possible with hipsterism and that authenticity cannot be reduced to 'mere subcultural rhetoric' (Schiermer 2014, 167); he interprets the adoption of past styles as a sincere attachment to particular facets of cultural expression and views the fusion of stylistic influences and reinterpretation of bourgeois 'emblems' and working-class kitsch as an expression of 'personal creative practice' (ibid. 169). Similarly, the hipsterist use of irony is more than mere 'Bourdieuian degout' (Schiermer 2014, 179) and is both a redemptive and imaginative challenge to notions of good taste; rather than simply representing the clichéd preoccupation of consumerist 'lemmings,' (Mount 2014), it can be read as an exploratory 'reaction to overt but unconscious imitation' (Schiermer, 179). This resonates with Sontag's conceptualisation of camp, in which she claims that 'taste has no system and no proofs' (Sontag 1964, 1) and that 'an object prized by camp ... arouses a necessary sympathy' (Sontag 1964, 8). It allows us to look at objects and aesthetics from other perspectives. In relation to that, Schiermer presents 'irony as a form of collective enjoyment of "failed objects" (Schiermer 2014, 179).

Regarding stereotyping, depicting men as camp is an established means by which to undermine their credibility as men. Depictions of effeminacy and idiocy combined feature prominently in the video Being a Dickhead's Cool (Dangor and Riley 2010). In this example of content recycling, a melange of imagery borrowed from a range of sources, including the blog HackneyHipsterHate, is presented in a flashing staccato format. An indiscriminate range of styles is used to refer to the title, and these include examples of 
high fashion but also forms of anti-fashion and those unrelated to hipsterism. This use of random theatricality is clearly intended to parody and in so doing it returns, again, to the premise that hipsterism is dependent on artifice and bad taste. Clearly, this video is intended to stereotype through a use of visual hyperbole and rejects any notion of the relative nature of taste (Bourdieu 1984), but this approach is also taken in apparently more measured media texts. Hipsters are represented as contrived in manner and style but this ignores the benefits of experimentation as an essential element for creativity and indeed the contention that 'bad taste is phenomenologically intriguing' (Schiermer 2014, 173).

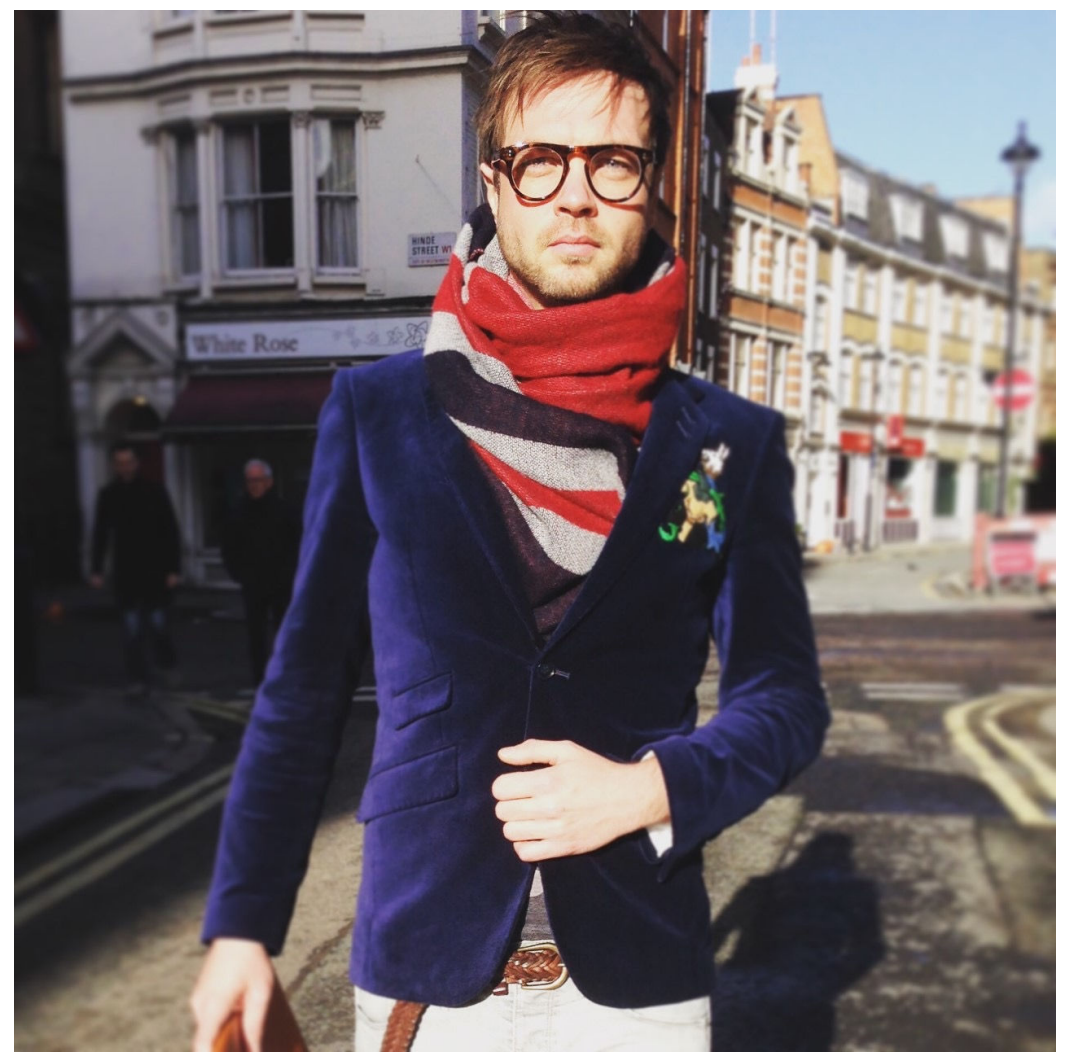

Fig. 3. All Buttoned Up, source: Gregor Clemens-Dobschutz 2015.

Despite many accusations of 'collective conformity' by the media (Zolfagharifard and Woollaston 2015), media coverage itself proposes a broad vestiary spectrum, which includes both the formal and the ludic. This playfulness is often conflated with the ludicrous, but can also be defended as a vital component in any cultural and aesthetic 
evolution, and I would concur that 'fashion is culturally omnivorous and dilettantish' (Fox 2016, 77) (see Figure 3.). On the other end of the stylistic spectrum, hipsterism can also express an aversion to ostentatious, branded fashion through an emphasis on simplicity. The Top Chump cartoon entitled 'The Art Collective Look' (Vice 2018) captures a normcore aesthetic, which far from eclipsing hipsterism, as claimed by some, is in fact an essential component of it (see Figure 4.).

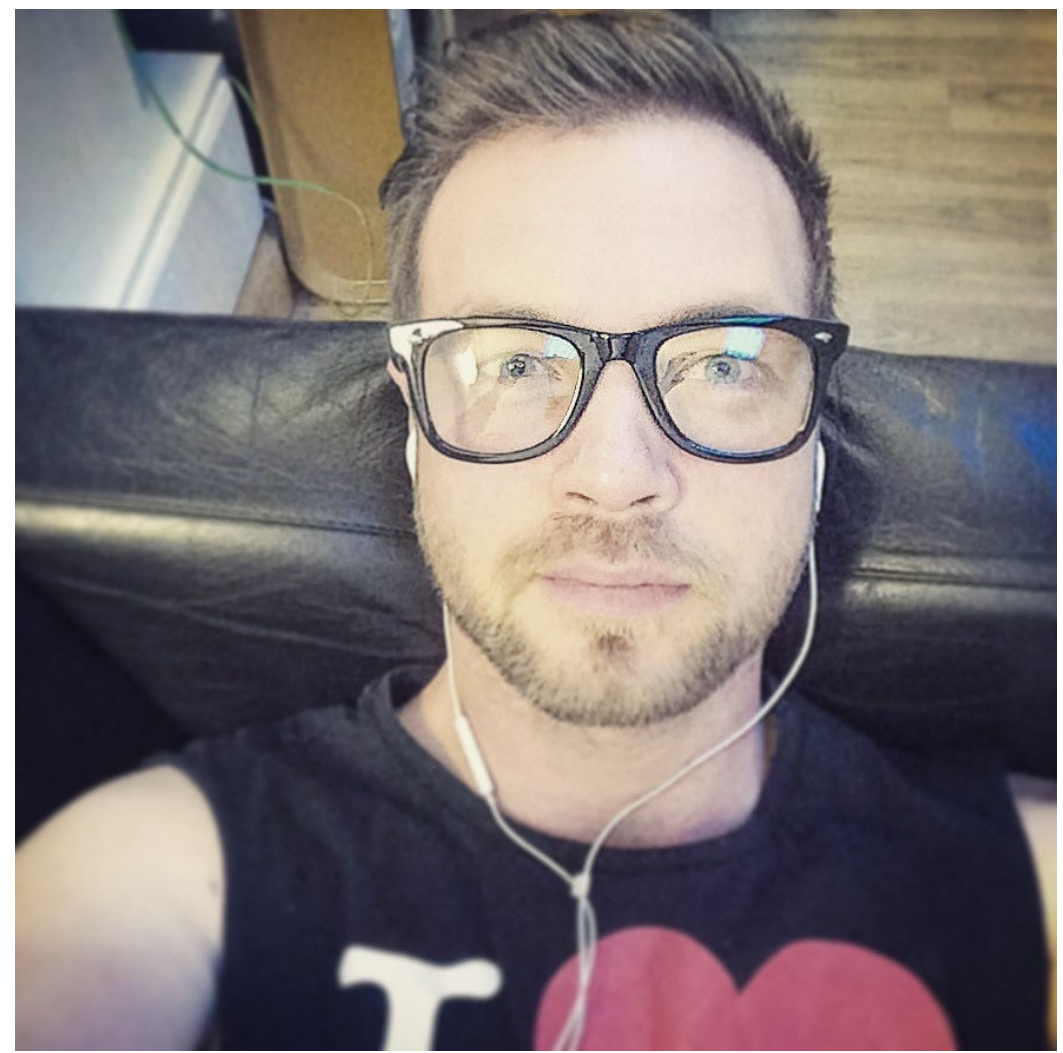

Fig. 4. Keeping it Simple, source: Gregor Clemens-Dobschutz 2014.

\section{Class, Anti-sociality and Neo-liberalism}

Hipsters are often identified as a young demographic, and their supposed antisocial behaviour in the form of both aloofness and inconsiderate hedonism is a major factor in attacks on them via social media. Certain sources refer to their styling itself as antisocial. Furthermore, being inconsiderate is presented as symptomatic of an elitism and class disdain that is bound up with gentrification. Hipsters are represented as 'posh' - a 
serious indictment in contemporary Britain. On social media variations of this include, in the words of blogger Raymanorac 'middle-class dickheads,' 'trustafarian posers' and 'double-barrel(sic) twats' (Hackney Hipster Hate 2010). The calumnious association between middle-class interlopers and socially damaging gentrification is repeatedly averred; as Richard Godwin notes 'in Dalston or Brixton, the mere act of buying a fancy coffee is sometimes depicted as an act of blundering white supremacy' (Godwin 2014). Wessendorf's study of community relations in multi-cultural Hackney identifies two demographics perceived as resistant to 'an ethos of mixing': Orthodox Jews and hipsters, who she defines as 'young, mostly middle-class people who emphasise fashion and style and have only recently moved into the area' (Wessendorf 2013, 408). This lends some credence to accusations of insensitivity but the breadth of her own definition of hipster also allows for the stereotyping of anyone approximating an interpretation of this category. As Chaney notes, 'lifestyles are patterns of action that differentiate people' (Chaney 1996. 4), and the media often reads this distinctiveness as superiority, and thereby conflates hipsterism with socio-cultural arrogance.

In September 2015, the anarchist group Class War organised a demonstration, advertised as the third Fuck Parade, on Facebook to protest, with torches, pig's heads and effigies, against a process of gentrification in Shoreditch, which they claimed was causing local communities to be 'ripped apart' (Khomaini and Hallyday 2015). Several premises were attacked but the only one to receive coverage in the media was the Cereal Killer Café run by two Irish brothers, Gary and Alan Keery, who found themselves and their customers under siege by a chanting crowd who daubed 'scum' on the window, which they then attempted to break. The identification of the brothers as quintessential hipsters was central to the media coverage. This was based not only on the brothers sporting full beards, occasionally man-buns, and a range of normcore plaid shirts, but also the specialist nature of their business: the brothers sold bowls of artisanal cereal for $£ 3.20$, and many reports, while voicing sympathy for the attack, also highlighted this as emblematic of niche forms hipsterism that are considered elitist and so provocative.

The accusation of elitism features prominently in a range of literature that considers the socio-economic significance of hipsterism (Greif, Ross and Tortorici 2010, Kinzey 2012, Zukin 2011). This American literature refers explicitly to hipsters as the embodiment of neo-liberal agendas that have altered the demographic nature of Brooklyn, to name one example, by replacing the indigenous white working class and people of colour in what is classed as act of social cleansing with intersectional significance. This accusation is also applied to British context in London, but Hugo Rifkind highlights the inherent dangers of making such easy correlations when he refers to hipsters as 'the modern canaries of urban gentrification' (Rifkind 2016). Hubbard (2016) is justified in cautioning against an undiscriminating adoption of a 'hipster led model' of gentrification in retail space by developers and councils (Hubbard 2016, 5) and consideration of differentials in cultural capital and consumer needs should be taken into account. However, to claim, on the basis of assumed lifestyle choices, that people who conform to a particular ideal type are responsible, either directly or indirectly, for social cleansing not only represents stigmatisation, but it also reflects an inability, or unwillingness to understand the context in which Londoners of all types operated during the period of this study. Clearly, certain individuals took advantage of the housing shortage and the rapid inflation of house prices that characterised this period; 
however, to lay the blame solely at the feet of hipsters completely ignores the essential role that national and local governance played in the facilitation of neo-liberal agendas and the failure to invest properly in deprived areas.

\section{Conclusion}

I conclude with several points. Firstly, from the media texts analysed in this study it is clear that hipsters have become stock characters in late modernity and are popularly acknowledged as corresponding to media representation. However, I would contend that this representation is a cultural construct that draws selectively on particular phenomena in lifestyle and consumption habits in order to assemble a twenty-first century Golem onto which a range of prejudices, anxieties and suspicions can be projected. The nuances of this demographic have proved difficult to identify, which has resulted in a catch-all label being applied, but not claimed, and then consolidated into an established stereotype.

Secondly, although this study focuses on negative representation, which dominates discourse on the subject, a close reading of media content reveals tonal dissonance between the established media, television and social media. This, though unsurprising in itself, also uncovers a varied and nuanced reception to hipsterism. The dominant assumption in the established press that cultural responses are negative, though on a sliding scale of opprobrium, is not uniformly borne out by the content itself, and more ambivalent reaction exists. However, the supposition of a negative discourse acts to substantiate this discourse, and by emphasising and repeating a litany of supposedly unappealing characteristics, the media then cements them. In social media, while there is very little identification as hipsters, assumptions and prejudices are challenged; however, discourse by bloggers is not only heavily gendered, it is also generally negative.

Thirdly, the conflation of hipster with men brings attitudes and responses to masculinity to the fore. The male hipster is the embodiment of cultural change in taste, and as with many such examples, these changes have been met with suspicion. Regarding appearance, much of the spirit, if not the detail of hipster style, has been evident throughout post-modernity: experimentation with normative gender roles, eclectic nostalgia and manifestations of subcultural capital that challenge established notions of taste. What is new, however, is an assumption that this reflects mere consumerism, which is an accusation that conveniently distracts from the rampant consumption firmly entrenched in society as a whole, and its vital role in the British economy. In no sense should this be read of an endorsement of the status quo, but these factors need to be recognised. While British attitudes to gender have changed considerably in recent decades, certain cultural beliefs persist and the notion that a man constructs an identity through experimentation not driven by 'deeper' convictions or traditional loyalties, such as sport or ideology, continues to render him both pretentious and insincere for many. Such a poseur is, by definition, inauthentic, and an accusation of privilege can only compound this inauthenticity. The geographical environment in which hipsters supposedly flourish is repeatedly cited as the terrain where socio-cultural differentials, highlighted by a hipster presence, exacerbate social inequality, and this is a gross simplification of socio-economic responsibilities. 
Finally, the mainstream adoption of a wide range of styles and practices has had a profound effect on menswear and male grooming; identity indexicals such as beards and skinny jeans, originally connotative of hipsters, have been adopted by an extremely wide demographic that exists far beyond the cultural clusters in Hackney. While the aesthetic qualities of either of these examples is clearly open to interpretation, these and other features at least contribute to a more hybridised form of masculinity, which I would contend is ultimately socially and culturally beneficial. Furthermore, outside fashion, other areas of material culture have also benefited from the 'hipster hype'. While this is precisely the argument provided by detractors as evidence of shallow consumerism and inauthenticity, this does not constitute any greater level of consumption; it merely comprises one that is distinct and one which offers alternatives to mass consumption.

Althusser, Louis; Étienne Balibar; Jacques Bidet; G. M Goshgarian. 2014. On the reproduction of capitalism: ideology and ideological state apparatuses. London: Verso.

Anderson, Eric. (2012) Inclusive masculinity: the changing nature of masculinities. New York: Routledge.

Barker, Chris. 2008. Cultural Studies: Theory and Practice, London: Sage.

Barthes, Roland. 1977. Image, Music, Text. London: Fontana Press

Becker, Howard S.1964. The Other Side: Perspectives on Deviance. New York: The Free Press.

Bennett, Andy. 1999. "Subcultures or Neo-Tribes? Rethinking the Relationship between Youth, Style and Musical Taste." Sociology: 33 (3): 599-617. Accessed June 5, 2016. http:// soc.sagepub.com/content/33/3/599.full.pdf + html

Berger, Asa. 2016. Media and Communication Research Methods: An Introduction to Qualitative and Quantitative Approaches, 4th Edition. London: Sage.

Berry, Matt (Writer), Arthur Matthews (Director). 2012-2015. Toast of London. Television Series. Accessed June 16, 2016. http://www.imdb.com/title/tt3266890/

Beynon, John. 2002. Masculinities and Culture. Buckingham: Open University Press.

Boorman, Neil, John Morgan and Mike Watson (Writers), Otto Bathhurst (Director). 2003. Shoreditchtwat TV: Accessed 12 June, 2016. https:// www.youtube.com/watch? $\mathrm{v}=\mathrm{GUeAz}$-eeOTI

Bot, Sophy. 2012. The Hipster Effect: How the Rising Tide of Individuality is Changing Everything we Know about Life, Work and the Pursuit of Happiness. New York: the hipstereffect.com

Bourdieu, Pierre. 1984. Distinction: A Social Critique of the Judgement of Taste. Cambridge: Harvard University Press.

Bourdieu, Pierre. 1993. The Field of Cultural Production. Cambridge, UK: Polity Press.

Broyard, Anatole. 1948 "Portrait of a Hipster." Partisan Review, June 1948. Accessed June 8, 2016. http://karakorak.blogspot.co.uk/2010/11/portrait-of-hipster-by-anatolebroyard.html

Chaney, David. 1996. Lifestyles. London: Routledge.

Glemens-Dobschutz, Gregor. 2015. "All Buttoned Up."

Glemens-Dobschutz, Gregor. 2014. "Keeping it Simple." 
Cobb, Russell. 2014. "Introduction: The Artifice of Authenticity in the Age of Digital Reproduction." In The Paradox of Authenticity in a Globalized World, edited by Russell Cobb. New York: Palgrave Macmillan.

Connell, Raewyn and James W. Messerschmidt. 2005. "Hegemonic Masculinity: Rethinking the Concept." Gender \& Society, 19 (6): 829-859.

Connell, Raewyn. 2005. Masculinities, second edition. Cambridge: Cambridge Polity Press.

Dacre, Karen. 2013. "Hackney v Brooklyn: Who's the Hippest of Them All?" Evening Standard, 9 July, 2013. Accessed June 10, 2016. http://www.standard.co.uk/ fashion/hackney-v-brooklyn-who-s-the-hippest-of-them-all-8697190.html

Dangor, Reuben and Raf Riley (Writers/Directors). 2010. "Being a Dickhead's Cool." Accessed June 14, 2016. https://www.youtube.com/watch?v=lVmmYMwFj1I

Demitriou, Demetrakis. Z. 2001. "Connell's Concept of Hegemonic Masculinity: A Critique." Theory and Society 30 (3): 337-361.

Durham, Meenakshi Gigi and Douglas Kellner. 2006 Media and cultural studies: keyworks. Revised ed. Malden, MA: Blackwell.

Dyer, Richard. 2013. Essay on Representations. London: Taylor and Francis.

Entwistle, Joanna and Agnes Rocamora. 2006. "The Field of Fashion Materialized: A Study of London Fashion Week." Sociology 40 (4): 735-751.

Ferrier, Morwenna. 2014. "The End of the Hipster: How Flat Caps and Beards Stopped Being Cool.” The Guardian, 21 June 2014. Accessed June 10, 2016. https://www.theguardian.com/fashion/2014/jun/22/end-of-the-hipster-flatcaps-and-beards

Fillitz, Thomas and Jamie Saris. 2015. "Authenticity Aujourd'hui." In Debating Authenticity: Concepts in Modernity in Anthropological Perspective , edited by Thomas Fillitz, and Jamie Saris. New York: Berghahn.

Florida, Richard. 2014. The Rise of the Creative Class. New York: Basic Books.

Flowerdew, John, and John E. Richardson. 2014. The Routledge Handbook of Critical Discourse Studies. London: Taylor and Francis.

Fox, Dan. 2016. Pretentiousness: Why It Matters. London: Fitzcarraldo.

Godwin, Richard. 2014. "Hipster is Just a Way to Slag Off the Young." Evening Standard, 1 October, 2014. Accessed June 152016.

http://www.standard.co.uk/comment/comment/richard-godwin-hipster-isjust-a-way-to-slag-off-the-young-9767412.html

Gramsci, Antonio, Quinten Hoare and Geoffrey Nowell-Smith, G. 1971. Selections from the prison notebooks of Antonio Gramsci. London: Lawrence and Wishart.

Greif, Mark. 2010. “The Hipster in the Mirror.” New York Times, 12 November, 2010. Accessed May 15, 2016 http://www.nytimes.com/2010/11/14/books/review/ Greif-t.html

Greif, Mark. 2010a. "What was the Hipster." New York, 24 October, 2010. Accessed May 15, 2016. http://nymag.com/news/features/69129/

Greif, Mark, Kathleen Ross and Dayna Tortorici (eds) 2010. What was the Hipster? A Sociological Investigation. New York: $\mathrm{n}+1$ Foundation.

Hackney Hipster Hate. 2010. Blog. Accessed June 5, 2016. http:// hackneyhipsterhate-blog.tumblr.com 
Haddow, Douglas. 2008. "Hipster: The Dead End of Western Civilization." Adbusters 29 July, 2008. Accessed June 10, 2016. http://www.adbusters.org/article/ hipster-the-dead-end-of-western-civilization/

Hebdige, Dick. 1988. Subculture: the meaning of style. London: Routledge

Hubbard, Phil. 2016. "Hipsters on Our High Streets: Consuming the Gentrification Frontier." Sociological Research Online, 21 (3): 1-6. doi: 10.5153/sro.3962

Jefferson, Tony and Stuart Hall. 1991. Resistance through rituals: youth subcultures in post-war Britain. London: Harper Collins Academic

Jones, Rodney, Alice Chik and Christoph Hafner (eds). 2015. "Introduction: Discourse and Digital Practices"In Discourse and Digital Practices: Doing Discourse Analysis in the Digital Age, edited by Rodney Jones, Alice Chik and Christoph Hafner. London: Routledge.

Jorgenen, Marianne and Louise Phillips. 2002. Discourse Analysis as Theory and Method. London: Sage. 2002

Khomami, Nadia and Josh Halliday. 2015 "Shoreditch Cereal Killer Café targeted in anti-gentrification protests." Guardian. 27 September. Accessed February 2, 2016 https://www.theguardian.com/uk-news/2015/sep/27/shoreditch-cerealcafe-targeted-by-anti-gentrification-protesters

Keightley, John. 2001. "Reconsidering Rock." In The Cambridge Companion To Pop and Rock (Cambridge Companions to Music), edited by Simon Frith, Will Straw and John Street. 109-142. Cambridge: Cambridge University Press.

Kinzey, Jake. 2012. The Sacred and the Profane: An Investigation of Hipsters. Winchester: Zero Books.

Lanham, Robert (Writer), Strong Graham (Director). 2016. Peter York's Hipster Handbook. Television Documentary. Accessed 30 November 2016.

Lukes, Steven. 1974. Power: A Radical View. London: Macmillan Press.

Machin, David and Andrea Mayr. 2012. How to Do Critical Discourse Analysis. London: Sage.

Mandle, Chris. 2014. "Everyone Hates Hipsters But Do The Really Exist." The Telegraph. 22 September 2014. Accessed August 20, 2016.

http://www.telegraph.co.uk/men/the-filter/11113544/Everyone-hateshipsters-but-do-they-really-exist.html

Mailer, Norman. 1971. The White Negro: Superficial reflections on the hipster. San Francisco: City Lights Books

Maffesoli, Michel. 1996. The Time of the Tribes: the Decline of Individualism in Mass Society. London: Sage.

Maly, Ico and Piia Varis. 2016. "The 21st-century hipster: On micro-populations in times of superdiversity." European Fournal of Cultural Studies.19 (6): 637-653. doi.org/10.1177/1367549415597920

McWilliams, Douglas. 2015. The Flat White Economy. London: Gerald Duckworth Books.

Morris, Chris and Brooker, Charlie (Writers), Chris Morris (Director). 2005. Nathan Barley. Television series. Accessed June 22, 2016. http:// www.channel4.com/programmes/nathan-barley

Michael, Janna. 2013. "It's really not hip to be a hipster. Negotiating trends and authenticity in the cultural field." Fournal of Consumer Culture, 0 (0): 1-20. doi.org/10.1177/1469540513493206 
Mommaas, Hans. 2004. "Cultural clusters and the post-industrial city: towards a remapping of urban cultural policy." Urban Studies, 41 (3): 507 - 532

Morton, John (Writer), John Morton (Director). 2011-2012. Twenty Twelve. Television Series. Accessed June 21, 2016. https://www.youtube.com/watch? $\mathrm{v}=\mathrm{xj} \mathrm{Y0784} \mathrm{vHN8}$

Morton, John (Writer), John Morton (Director). 2014. W1A. Television Series. Accessed June 25, 2016. https://www.youtube.com/watch?v=4tN JyEq3A8

Mount, Harry. 2014. "It's Time to Shave that Beard: the Decade of the Hipster is Over." Spectator, October 25, 2014. Accessed 14 June 2016. http:// www.spectator.co.uk/2014/10/its-time-to-shave-that-beard-the-decade-of-thehipster-is-over/

Muggleton, David, and Rupert Wienzierl. 2003) "What is Post-Subcultural Studies.” In The Post-Subcultures Reader, edited by David Muggleton and Rupert Wienzierl, 3-27. Oxford: Berg.

O’Neil, Luke. 2013. "It's Hip to be Hip, too.” Slate.com. 23 September 2013. Accessed June 19, 2016.

http://www.slate.com/articles/life/culturebox/2013/09/ proud_of_being_a_hipster_one_bearded_indie_rock_loving_contrarian_article. $\underline{\mathrm{html}}$

Peral, Luis. 2015. "Self Portrait in a Bowler Hat." photo.

Peral, Luis. 2016. "Taking in the Scene." photo.

Pickering, Michael. 1995. "The Politics and Psychology of Stereotyping." in Media Culture \& Society: 17 (4):691-700

Proud, Alex. 2014. 'Why this "Shoreditchification" of London Must Stop', The Telegraph Lifestyle, 13 January 2014. Accessed June 20, 2016. http:// www.telegraph.co.uk/men/thinking-man/why-this-shoreditchification-oflondon-must-stop/

Rifkind, Hugo. 2015. "Don't Blame Hipsters for Pop-Up Gin Bars." The Times. 29 September 2015. Accessed June 10 2016. http://www.thetimes.co.uk/tto/ opinion/columnists/article4570415.ece

Schiermer, Bjorn. 2014. "Late-modern hipsters: New Tendencies in Popular Culture." Acta Sociologica: 57(2): 167-181. Accessed 1 May 2016. http:// asj.sagepub.com/content/57/2/167.short?rss=1\&ssource $=\mathrm{mfr}$

Shields, Rob. 1992. "Spaces for the Subject of Consumption." In Lifestyle Shopping: the subject of consumption, edited by Rob Shields, 1-21. London: Routledge.

Sontag, Susan. 1964. Notes on Camp. Accessed May 28, 2016.

http: / / faculty.georgetown.edu/irvinem/theory/SontagNotesOnCamp-1964.html

Taylor, Charles. 1991. The Ethics of Authenticity. Cambridge, MA: Harvard University.

Thornton, Sara. 1995. Club Cultures. Music Media and Subcultural Capital. Cambridge: Polity.

Vannini, Phillip and Patrick J. Williams. 2009. "Authenticity in Culture, Self and Society." In Authenticity in Culture, Self and Society, edited by Phillip Vannini and J. Patrick Williams. 1-21 Abingdon: Ashgate Publishing.

Varga, Somogy. 2012. Authenticity as an Ethical Ideal. London: Routledge.

Vice. Blog. Accessed January 2, 2018. https://www.vice.com/en uk/article/8gmwbg/ top-chumps 
Warrington, Ruby. 2010. "Enough Already." The Sunday Times, 28 November 2010. Accessed May 28, 2016. http://www.thesundaytimes.co.uk/sto/style/fashion/ trends/article453527.ece

Wessendorf, Susanne. 2013. "Commonplace diversity and the 'ethos of mixing': perceptions of difference in a London neighbourhood." Identities: Global Studies in Culture and Power, 20 (4) : 407-422. doi.org/10.1080/1070289X.2013.822374

Wilson, Elizabeth. 2003. Adorned in Dreams, revised edition. New Brunswick: Rutgers University Press.

Zukin, Sharon. 2010. Naked City: The Death and Life of Authentic Urban Places. Oxford: Oxford University Press.

Zolfagharifard Ellie,Victoria Woollaston. 2015. "Why all hipsters look the SAME: Scientists reveal the maths behind beards, bicycles and man buns." March 10, 2015. Accessed September 24, 2017.

http://www.dailymail.co.uk/sciencetech/article-2986776/Why-hipsters-lookScientists-reveal-maths-beards-bicycles-man-buns.html

Charlie Athill is a lecturer in Cultural and Historical Studies at the London College of Fashion (LCF), one college of the University of the Arts London. With a specialist role in International Collaborative Provision, he works on developing the cultural and historical studies contribution to international projects in fashion design and media between the London College of Fashion and overseas institutions. He also works on all levels of undergraduate study in all three schools at LCF: Fashion Business, Fashion Design and Technology and Fashion Media. A member of the Extreme Anthropology Network, his current research interests include the effects of ageing on body image and sexuality and also the experience of international students in the United Kingdom in relation to differences in cultural and pedagogical histories. c.athill@fashion.arts.ac.uk 